Trivent Publishing

(C) The Authors, 2016

Available online at http://trivent-publishing.eu/

Series: Philosophy, Communication, Media Sciences

Volume: Communication Today: An Overview from Online Journalism to Applied Philosophy

\title{
The Europeanization of Cities - A preliminary Assessment of Romanian Cities Competing for the 2021 European Capital of Culture Title
}

\author{
Corina Turșie \\ Department of Politics, West University of Timisoara, Romania, corina.tursie@e-uvt.ro
}

\begin{abstract}
Within the context of Multi-level European Governance, cities were given a new political space to exploit. This paper presents various forms of top-down and bottom-up dynamics of Europeanization, such as participation to urban networks, accession of territorial cooperation funds and participation to twinning agreements. These indicators of Europeanization are verified in the case of Romanian cities competing for the 2021 European Capital of Culture (ECoC) title, as an initial assessment of the ongoing national competition. Without having the pretention that this assessment has any predictive purpose, given the complexity of the ECoC competition, the results of this study confirm mostly the shortlist of Romanian finalist cities issued in December 2015. This analysis shows that the ECoC title is disputed by the most Europeanized cities, even if they are ex-communist cities, latecomers to the process of European integration.
\end{abstract}

\section{Keywords}

Europeanization; European Capital of Culture; urban networks, territorial cooperation; URBACT II; INTERREG IV C; twin agreements.

This is an Open Access article distributed in accordance with the Creative Commons Attribution Non Commercial (CC-BYNC-ND 4.0) license, which permits others to copy or share the article, provided original work is properly cited and that this is not done for commercial purposes. Users may not remix, transform, or build upon the material and may not distribute the modified material (http://creativecommons.org/licenses/by-nc/4.0/)

DOI: $10.22618 /$ TP.PCMS.20164.349020 


\section{The Europeanization}

Corina Turșie

\section{Multilevel governance and Europeanization: new political spaces for cities}

Much of the literature on multilevel governance and Europeanization appeared at the end of the 1980s and early in the 1990s. ${ }^{1}$ It was as a reflection of the extension of European Union (EU) policies; among them, the regional and cohesion policy, which was introduced in the Single European Act in 1986, followed by the adoption of Structural Funds Regulation in 1988, represented drivers of change, related to the European political space. The triadic multi-level approach to European politics and the Europeanization perspective starts from 'the presence of three levels of political organisation in the EU - the European, the national and the local- and suggests that the interactions between them constitute a new form of politics." ${ }^{2}$ There is a growing literature on the shift from traditional Government towards governance, a 'reallocation of authority upwards, downwards and sideways from central states. ${ }^{3}$ The shift leads upwards to the supranational scale, and downwards to the regional and urban scale. These vertical and horizontal dynamics represent the essence of Europeanization, as means by which multi-level governance is implemented. It was argued that Europeanization encompasses three aspects ${ }^{4}$ : first, the domestic impact of EU institutions, and of its legal and financial instruments (top-down vertical Europeanization); secondly, the impact of the actions/lobby of EU Member States' authorities (even of local level) on EU institutions (bottom-up vertical Europeanization); third, at the local level, European local structures, such as cities, are becoming more Europeanized because they cooperate transnational, exchange experiences and develop jointly innovative solutions for shared problems (horizontal Europeanization).

More and more attention is being paid to different vertical or horizontal governance arrangements in which cities could be involved. Following the ongoing process of globalization, cities are facing new challenges, as well as new opportunities. They are competing for resources, such as EU funds and within this process, they are also trying to build an attractive image. It is also argued that European cities 'gain new room for political manoeuvre because the process of Europeanization implies an opening-up of new political sphere in which cities can play a new multi-level game, or traditional structures of domestic policy-making can be by-passed. ${ }^{5}$

This process of internationalisation of cities allows 'local decision makers (to) become part of a world that is more complex, changeable and interdependent than national politics. ${ }^{6}$ As a result of EU programmes, regions and cities "have become more international in their outlook and in their willingness to become involved in regions with similar characteristics/problems. ${ }^{7}$ The international outlook of cities was analyzed in Marta Lackowska's study ${ }^{8}$ on Europeanization of post-socialist polish cities, as a type of outward rescaling. She identified three forms of city's internationalization strategies: networking (participation to urban networks), bilateral (twinning agreements) and individual activity (accession of EU funds, organizing big events, such as the European Capital of Culture, in order to improve the international visibility of the city).

Following these ideas, ECoC can be seen as an Europeanization tool. In the views of many observers, the impact of the EU is not just the sum of its policies, strategies and transferred money, but

\footnotetext{
${ }^{1}$ The seminal works of Gary Marks, starting with "Structural policy and Multilevel Governance in the EC" in The State of the European Community, ed. A. Cafruny and G. Rosenthal (Boulder: Lynne Rienner, 1993), 391411.

${ }^{2}$ P. John, “The Europeanization of Sub-national Governance”, Urban Studies 37, 5-6 (2000): 882.

${ }^{3}$ G. Marks, L. Hooghe, "Unraveling the Central State, But How? Types of Multi-Level Governance" Political Science Series 87 ( 2003): 2-19.

${ }^{4}$ K. Kern and H. Bulkeley, "Cities, Europeanization and Multi-level Governnace: Governing Climate Change through Transnational Municipal Networks" Journal of Common Market Studies 47-2 (2009): 312.

${ }^{5}$ H. Heinelt and S. Niederhafner, "Cities and organized interest intermediation in the EU multi-level system", European Urban and Regional Studies 15-2 (2008): 173.

${ }^{6}$ P. John, “The Europeanization of Sub-national Governance", Urban Studies 37, 5-6 (2000): 877.

${ }^{7}$ N. Rees apud H. Leitner and E. Sheppard, " 'The City is Dead, Long Live the Net': Harnessing European Interurban Networks for a Neoliberal Agenda”, Antipode (Malden: Blackwell Publishers, 2002), 510.

${ }^{8}$ M. Lackowska, "Polish Cities Face the EU - Europeanization of Post-Socialist Cities as a Type of Outward Political Rescaling", Croation and Comparative Public Administration (2014): 31-58.
} 
EU also produces Europeanization, by transferring 'ideas and working practices that can transform politics at the local level away from nationalised and hierarchical forms of politics towards more negotiated and interdependent practices ${ }^{\prime 9}$. Peter John considers that it is only when local authorities 'start to incorporate European ideas into their policies that they become fully europeanised.' 10

Created in 1985, the ECoC programme originally intended to bring Europeans together and to highlight the richness and diversity of European culture. Today, ECoC it is regarded as the most prestigious and popular European cultural event. Cities are supposed to organize a one year long cultural programme, highlighting the city's European dimension and the importance of citizens' participation to culture; they also have to make proof of their ability to manage a complex cultural event. It was rapidly evident that the Program's impact went beyond the cultural and political aspects as 'cities recognized that the designation was a marketing opportunity to improve image on a national and European scale and constituted a sort of regeneration tool.' ${ }^{11}$ This regeneration opportunity is strongly advocated by 'latecomer cities from Central and Eastern Europe, aspiring to overcome marginality ${ }^{\prime 2}$ by winning the title. At the same time, it has been argued that hosting an ECoC requires large public investments and that the title was regularly hosted in regions with above-average GDP per capita $^{13}$. This informal precondition is harder to be achieved by Central and Eastern European cities, known for their regions with the lowest GDP per capita. Regardless of their richness, the credibility of these cities as potential capitals of culture and also their persuasiveness as candidates, can be sustained by proofs of existent Europeanization processes: already established cooperation structures and implemented strategies and investments. From this point of view, a final ECoC application is a document whose main objectives 'are based on strategies actually pursued by local decision-makers and embedded to a significant extent in the local context. ${ }^{14}$

This paper addresses the subject of Europeanization of Romanian cities competing for the 2021 European Capital of Culture $(\mathrm{ECoC})$ title. In my research I will use the following variables: first, participation to urban networks, secondly, accession of territorial cooperation financing schemes and third, the existence and promotion of twinning agreements. Each of these variables has its own rationale and represents incentives of cities' Europeanization.

\section{A. Participation to urban networks and regional financing schemes}

A network discourse has emerged since the 1980's, presenting networks as 'an alternative to markets and hierarchies. ${ }^{15}$ The concept of multi-level governance is associated with the "network character of European governance. ${ }^{16}$ Following a neoliberal discourse, we are witnessing a 'complex rescaling of political power, ${ }^{17}$ providing 'new political spaces for localities' ${ }^{18}$. Within this perspective, networks

\footnotetext{
${ }^{9}$ P. John, "The Europeanization of Sub-national Governance", Urban Studies 37, 5-6 (2000): 877.

10 Idem, 882.

${ }^{11}$ G. Cogliandro, "European cities of culture for the Year 2000: A wealth of urban cultures for celebrating the turn of the century", Association of the European Cities of Culture of the year 2000 (2001), 8.

${ }^{12}$ Alexander Tolle, "Transnationalism of development strategies in East Central European cities: A survey of the shortlisted Polish European Capital of Culture candidate cities", European Urban and Regional Studies 0 (2013) : 1. http://eur.sagepub.com/content/early/2013/12/29/0969776413512845.full.pdf+html (accessed December 2015).

${ }^{13}$ L. Steiner, B. Frey and S. Hotz, "European Capitals of Culture and life satisfaction", Urban Studies 52-2 (2015): 374 .

${ }^{14}$ Idem, 3.

${ }^{15}$ H. Leitner and E. Sheppard, “"The City is Dead, Long Live the Net': Harnessing European Interurban Networks for a Neoliberal Agenda", Antipode (Malden: Blackwell Publishers, 2002): 496.

${ }^{16}$ K. Kern and H. Bulkeley, "Cities, Europeanization and Multi-level Governnace: Governing Climate Change through Transnational Municipal Networks”, Journal of Common Market Studies 47-2 (2009): 309.

${ }^{17}$ Idem, 511.

18 Idem, 509.
} 
are 'a preferable mode of coordination and governance for coping with the vagaries of globalisation (...) increasing competitiveness, generating economic growth and resolving social problems. ${ }^{19}$

These new political spaces for cities can be filled by different forms of collective action: partnerships between central and sub-national governments, public-private partnerships, transnational urban networks, such as Eurocities or the Council of European Municipalities and Regions (CEMR).

Urban networks are generally being characterized by a bottom-up initiative (anyone can initiate and join), ${ }^{20}$ and a collaborative, non-hierarchical functioning, promoting learning and the diffusion of best practices. They also have a topological role, linking horizontally participants who were never connected, more and less successful cities.

The European Commission has encouraged the creation of transnational urban networks since the introduction of the regional policy, as a modality to reduce economic and social disparities within the EU. It created special financing sources available to cities for territorial cooperation, designed to develop cross-border cooperation (INTEREG) or Community initiatives (URBAN, URBACT).

The participation of cities to transnational urban networks, the extent and intensity of their involvement, as well as their accession of INTEREG or URBACT funds is a sign of their Europeanization.

\section{B. Twinning Agreements}

As well as urban networks, twinning agreements can be viewed from a neoliberal perspective on society and governance, as a bilateral activity 'which <produces proximities $>$ as part of urban <statecraft> involved in a <new politics of scale> and <localism> and through the activities of $<$ bottom-up $>$ social movements. ${ }^{21}$

Today's practice of city twinning goes back to the end of the Second World War and it has proliferated around the world as an expression of 'hospitality and friendship'22 between cultures. It represents the traditional method of internationalization of cities, with 'a strong <political> aim of preventing yet another conflict by fostering peaceful contacts in culture, sports, and education between the nations' ${ }^{23}$. It was considered 'the most bottom-up form of International relations, leaning on the activities of local communities and escaping any top-down rules. ${ }^{24}$ Following the argumentation that 'the study of twinning offer vital insights into the transnationalization of society and culture, ${ }^{25}$ twinning behaviour, in terms of partnership for civic visitation, educational exchanges and cultural cooperation can be viewed as a sign of cities' Europeanization.

\section{Data and methodology}

Within the ECoC legislative framework Romania is one of the alleged countries to host an ECoC in 2021. Several cities have officially stated their interest in holding the title: Arad, Alba Iulia, Baia Mare, Brașov, Brăila, București, Cluj-Napoca, Craiova, Galați, Iași, Sfântu Gheorghe, Suceava, Târgu Mureș or Timișoara. According to the ECoC schedule for 2021, the short list of Romanian candidate cities is to be announced in December 2015, after a preliminary evaluation. A lot of opinions were vehiculated in the Romanian public space, regarding the chances of each city to win the title.

19 H. Leitner and E. Sheppard, 'The City is Dead, Long Live the Net': Harnessing European Interurban Networks for a Neoliberal Agenda", Antipode (Malden: Blackwell Publishers, 2002): 495.

${ }^{20}$ Idem, 502.

${ }^{21}$ M. Jayne, P. Hubbard and D. Bell, "Twin Cities: Territorial and Relational Geographies of 'Wordly' Manchester", Urban Studies 50-2 (2013): 240.

${ }^{22}$ Idem, 250.

${ }^{23}$ M. Lakowska, "Polish Cities Face the EU - Europeanization of Post-Socialist Cities as a Type of Outward Political Rescaling", Croation and Comparative Public Administration (2014): 43.

${ }^{24}$ Ibidem.

${ }^{25}$ M. Jayne, P. Hubbard and D. Bell, "Twin Cities: Territorial and Relational Geographies of 'Wordly' Manchester", Urban Studies 50-2 (2013): 241. 
My study aims to perform an initial analysis of the 14 Romanian candidate cities, assesing whether they have a suitable Europeanized ECoC winner profile, using existing public data. This research is motivated by an assumption: a title which is suppose to show the European dimension and cultural richness of a city cannot be won by one, without having a certain level of prior Europeanization. Guided by these ideas, this study presents a comparative evaluation of the degree of Europeanization of the 14 candidate cities, as an early evaluation of the winning incentives.

I will assess the Europeanization of the Romanian ECoC candidate cities at three levels, according to the variables presented in the previous section. First, I will assess Romanian cities' participation to urban networks, as a sign of horizontal Europeanization, with bottom-up opportunities. I will insist on cities' participation to two selected networks: Eurocities and CEMR. While CEMR is an organization created in 1951, gathering national associations of municipalities and regions, Eurocities is an organisation created in 1992, based on direct membership of big cities. Second, this study will asses Romanian cities participation to INTEREG IVC and URBACT II programmes, which were available for the financial period 2007-2013. The beginning of the financial perspective happily coincides with Romanian accession to the EU. Accession to EU available funds is to be seen as a sign of top-down Europeanization with horizontal Europeanization opportunities. Third, I will assess the twinning practices of Romanian candidate cities as a sign of horizontal Europeanization. The conclusions of this study will offer a preliminary assessment of the potential winner profile of the Romanian candidate cities to the ECoC title.

The Data used were found either on the websites of the City Halls of the competing cities, and on the websites of INTEREG IVC and URBACT Programes, either were obtained through other demarches. I have registered on $3^{\text {rd }}$ of November 2015 several requests, based on the Law 544/2001 on free access to public information, using either the applications existent on city halls websites or I have directly written emails to City Halls PR or International Relations Offices. I demanded information regarding the urban networks memberships and the twinning agreements of the cities (where it didn't already exist on the websites). Alba Iulia, Baia Mare, Brasov, Bucharest, Sf. Gheorghe and Timisoara proved to be responsive cities. Baia Mare and Timisoara are the only cities which contacted me twice in order to elaborate an answer according to my specific demands, even though the final information received was not complete.

The International Relations Office of Timisoara City Hall contacted me first by phone and then by email, sending me the required information within the agreed period of time, of two weeks, and agreeing, at my request, the preparation of an even more detailed response, further on. That second response never came.

The Alba Iulia City Manager answered my email within 9 days, transferring me an archived folder of available information regarding the City. The folder does not contain all the requested information. Brasov Public Information and Mass Media Office answered to my request in 9 days, sending me all the requested documents. Bucharest General City Hall answered on 19 November with a complex address gathering answers from three services (Office for Decisional Transparency, General Direction for Development and Investments and General Direction for Urban Development) containing partially the required information, and indicating the potential source of the missing information. Sf. Gheorghe Town Image Office answered within 3 days with short, but competent, information. Cluj Napoca City Hall International Affairs and Foreign Investment Department answered to my request the same day, announcing the forwarding of my demand to Cluj 2021 Association, from whom I received no answer. I didn't register a request to Iasi Municipality, for example, because all the information I needed, already existed on their website.

\section{Europeanization of Romanian ECoC candidate cities}

\section{A. Horizontal Europeanization through participation to urban networks}

The initial data used for my research is represented by the City Halls websites. I used the information available there in order to obtain a first input for my research - the urban networks in which the 14 
Romanian candidate cities for the ECoC title are involved in (Table 1). I noticed that a minority of cities - Alba Iulia, Arad and Iași - displayed on their website complete information regarding all their memberships to urban networks. Other city - Braşov - displayed partial information, related to some of their memberships. For the remaining cities, the information was collected by the author, following two types of demarches: the responses to the official requests based on the 544/2001 Law and Internet research. For this reason, the information is missing in some cases, but this only shows the lack of transparency of some City Halls or their lack of preoccupation related to the opportunities offered by urban networks.

Table 1. Urban networks memberships of the Romanian cities competing for the 2021 ECoC title (author's compilation of public data, city Halls websites and official email correspondence)

\begin{tabular}{|c|c|c|c|c|c|}
\hline No. & City & Urban Network & $\begin{array}{l}\text { No. of } \\
\text { memberships }\end{array}$ & $\begin{array}{l}\text { Information } \\
\text { available on } \\
\text { the City Hall } \\
\text { Website }\end{array}$ & Rank \\
\hline 1 & Alba Iulia & $\begin{array}{l}\text { Convenant of mayors, } \\
\text { TRANSROMANICA The Romanesque } \\
\text { Routes of European Heritage, } \\
\text { LOGICALTOWN for the promotion of the } \\
\text { culture of sustainable city logistics, ICLEI } \\
\text { - Local Governments for Sustainability, } \\
\text { Romanian Municipalities Asociation } \\
\text { [Asociația Municipiilor din România] }\end{array}$ & 6 & $\underline{\text { Yes }}$ & 2 \\
\hline 2 & Arad & $\begin{array}{l}\text { Convenant of mayors, A.V.E.C. [Alianţa } \\
\text { Oraşelor Europene ale Culturii], European } \\
\text { Social Network, Le Club de Strasbourg, } \\
\text { Romanian Municipalities Asociation } \\
\text { [Asociația Municipiilor din România] }\end{array}$ & 5 & $\underline{\text { Yes }}$ & 3 \\
\hline 3 & Baia Mare & Romanian Municipalities Asociation & 1 & No & 6 \\
\hline 4 & Brașov & $\begin{array}{l}\text { Energy Cities, Convenant of mayors, } \\
\text { A.V.E.C - Alianța Orașelor Europene ale } \\
\text { Culturii }\end{array}$ & 3 & $\begin{array}{l}\text { Partially (only } \\
\text { membership } \\
\text { to Energy } \\
\text { Cities is } \\
\text { promoted) }\end{array}$ & 4 \\
\hline 5 & Brăila & & - & No & 14 \\
\hline 6 & București & $\begin{array}{l}\text { AIMF (Association Internationale de } \\
\text { Mairies Francophones), Energy Cities, Le } \\
\text { Club de Strasbourg }\end{array}$ & 3 & No & 4 \\
\hline 7 & $\begin{array}{l}\text { Cluj } \\
\text { Napoca }\end{array}$ & $\begin{array}{l}\text { Convenant of mayors, European Social } \\
\text { Network }\end{array}$ & 2 & No & 5 \\
\hline 8 & Craiova & & - & No & 14 \\
\hline 9 & Galați & & - & No & 14 \\
\hline 10 & Iași & $\begin{array}{l}\text { AIMF (Association Internationale de } \\
\text { Mairies Francophones), Historic cities } \\
\text { League, } \\
\text { ENERGIE-CITES, Convenant of Mayors, }\end{array}$ & 5 & $\underline{\text { Yes }}$ & 3 \\
\hline
\end{tabular}




\begin{tabular}{|c|c|c|c|c|c|}
\hline & & $\underline{\text { Le Club de Strasbourg }}$ & & & \\
\hline 11 & $\begin{array}{l}\text { Sf. } \\
\text { Gheorghe }\end{array}$ & Convenant of mayors & 1 & No & 6 \\
\hline 12 & Suceava & & - & No & 14 \\
\hline 13 & Tg. Mureș & Convenant of mayors & 1 & No & 6 \\
\hline 14 & Timișoara & $\begin{array}{l}\text { Eurocities, Balcinet, Alliance of Iosef } \\
\text { Cities, European Cities marketing, Cities } \\
\text { for Sport, Les Rencontres [Asociaţia } \\
\text { Orasselor şi Regiunilor Europene pentru } \\
\text { Cultură]/ Like (the new name since 2015), } \\
\text { EU Core cities, Le Club de Strasbourg, } \\
\text { Energy Cities, Convenant of mayors, }\end{array}$ & 10 & No & 1 \\
\hline
\end{tabular}

Following this available information, Timișoara seems to be, by far, the most contected city in relation to European urban networks, followed by Alba Iulia, Arad, Iași, București and Brașov. It is important to note that only Alba Iulia and Arad are mentioning their belonging to Romanian Municipalities Asociation [Asociaţia Municipiilor din România - AMR], which is the Romanian national Association, part of the Council of European Municipalities and Regions. Founded in 1951, CEMR is probably the most important structure of formal representation of national municipalities associations, 'an international umbrella association of national local government associations' ${ }^{26}$. Founded in 1990, AMR includes today all 109 Romanian municipalities (including the districts of the Municipality of Bucharest). It is important to note that AMR has a representation office in Brussels, while no Romanian individual municipality has a similar office in the capital of Europe. The current Executive Board of AMR, elected by the General Assembly in June 2015, has 31 members. The President is the Mayor of the $3^{\text {rd }}$ district of Bucharest, and among the ECoC candidate cities, several mayors have representation positions: the Mayors of Arad and Craiona (Deputy Vice-Presidents), the Mayors of Timisoara and of the $2^{\text {nd }}$ District of Bucharest (Vice-Presidents), the Mayor of Brăila (General-Secretary), the Mayors of Baia Mare, $1^{\text {st }}$ district of Bucharest, Galați, Sf. Gheorghe (Members), the Mayors of the $6^{\text {th }}$ District of Bucharest and of Iași (Alternate Members). AMR is represented by the President of its Executive Board in the power structures of CEMR: he is a member of the Policy Committee of CEMR, its main governing organ, elected by the CEMR General Assembly; he is also a member of the Executive Bureau of CEMR, responsible for carrying out decisions of the Policy Committee. It has been argued that the participation to CEMR of the national associations is determined by political games: 'the results of local elections determine, together with regional criteria, the composition of the delegation sent to the organs of CEMR. ${ }^{27}$ In a similar manner, we can question whether the composition of the Executive Board of AMR is not also the result of party-oriented fractions, than a reflection of City administration dynamic and involvement in the activity of the Association. CEMR has five themes of group activity (Democracy, citizenship and enlargement, Resource efficiency and environment, Partnership, cooperation and world affairs, Economic, social and territorial cohesion, Local and regional governments as employers and service providers) all having several subthemes. None of them are being coordinated by a Romanian Mayor or policy officer, which may be a sign of the low intensity of Romanian implication in CEMR.

Unlike CEMR, Eurocities is an important European urban network created in 1992, reuniting big European cities (over 250.000 inhabitants). This organization is built on the direct participation of individual cities, 'able to act independently from their associations or umbrella organizations, ${ }^{28}$.

\footnotetext{
${ }^{26}$ H. Heinelt and S. Niederhafner, "Cities and Organized Interest Intermediation in the EU Multi-level System", European Urban and Regional Studies 15-2 (2008) : 177.

${ }^{27}$ Ibidem.

${ }^{28}$ Idem, 181.
} 
Compared to these umbrella organizations, Eurocities 'has advantages concerning particular knowledge or policy solutions' and it is clearly concentrating on EU policies. ${ }^{29}$ Giving this important know how opportunity, it is interesting to see that among the 14 Romanian cities only one, Timisoara, is a Eurocities member. In comparison, Poland, which holds in 2016 the ECoC title, has 12 cities within Eurocities, one of them being Wroclaw, the 2016 ECoC winner. From the information received from Timisoara City Hall International Relations Office, results that Timisoara is an associated member of Eurocities since 2000 and a full member since 2007. Among the identified benefits of membership such as 'access to publications, reports, researches, European best practices on issues of interest for cities, access to databases regarding policies and European financing programmes, ${ }^{30}$ Timisoara acknowledges the importance of 'increasing European visibility. ${ }^{31}$ The importance of networking it is also suggested as an opportunity to "learn from innovative practices of other cities within the network, partnerships for the participation to European transnational projects. ${ }^{32}$ The lobby opportunity in relation to EU institutions is also acknowledged, because through this network there can be formulated 'positions related to diverse European documents and legislation during their elaboration, with the result of influencing European policies which affect cities and citizens. ${ }^{33}$ This is a formulation of the true bottom-up Europeanization opportunity which urban networks such as Eurocities provide. There is little information regarding Timisoara's actual involvement in the activities of Eurocities, and Timisoara City Hall did not provide further information to my request.

\section{B. Top-down vertical Europeanization through accession of EU regional funds}

In order to asses Romanian ECoC candidate cities' accession of EU funds I have targeted two financing schemes available for cities - URBACT II and INTERREG IV C - within the Cohesion policy's goal of European Territorial Cooperation, in the financial perspective 2007-2013.

According to official data available on URBACT website, this programme is aiming to foster sustainable integrated urban development in cities across Europe. It is co-financed by the European Regional Development Fund, the 28 Member States, Norway \& Switzerland.

URBACT's mission is to enable cities to work together and develop integrated solutions to common urban challenges, by networking, learning from one another's experiences, drawing lessons and identifying good practices to improve urban policies. By providing EU funds, URBACT is an example of top-down Europeanization which may lead to horizontal Europeanization, in the form of creating urban temporary networks.

Collecting the data regarding the accession of URBACT II (2007-2013) programme (Table 2), it results that out of the 14 candidate cities, only 10 were involved in an URBACT project since Romania joined de EU. Alba Iulia, Baia Mare, Iasi and Suceava have been the most dynamic cities. They joined cities' networks and won funding for diverse urban projects related to urban renewal, disadvantaged neighborhoods, civic participation, Entrepreneurship and Small and Medium Enterprises (SMEs) and cultural heritage. As we can observe, no Romanian city is the Leading Partner of an URBACT project.

\footnotetext{
${ }^{29}$ Idem, 183.

${ }^{30}$ D. Donawell, "Timisoara City Hall- Associations and International Urban Network", Timisoara City Hall International Relations Office, Official email correspondence (December 2015): 1.

${ }^{31}$ Ibidem.

${ }^{32}$ Ibidem.

${ }^{33}$ Idem, 2.
} 
Table 2. URBACT projects implemented by Romanian ECoC candidate cities, 2007-2013 (author's compilation of official data available on URBACT website)

\begin{tabular}{|c|c|c|c|c|c|c|}
\hline Ranking & City & $\begin{array}{l}\text { URBACT } \\
\text { project }\end{array}$ & $\begin{array}{l}\text { Period of } \\
\text { implementation }\end{array}$ & $\begin{array}{l}\text { Leading } \\
\text { City/Partner }\end{array}$ & Topic & $\begin{array}{l}\text { Total } \\
\text { Budget }(€)\end{array}$ \\
\hline \multirow[b]{5}{*}{1} & Alba Iulia & City Logo & 2013-2015 & Utrecht (Ne.) & $\begin{array}{l}\text { City Branding, } \\
\text { Culture \& } \\
\text { Heritage }\end{array}$ & 713958,00 \\
\hline & Alba Iulia & CoNet & 2008-2011 & Berlin (Ge.) & $\begin{array}{l}\text { Disadvantaged } \\
\text { Neighborhoods } \\
\end{array}$ & $\begin{array}{l}644 \\
319,41 \\
\end{array}$ \\
\hline & Alba Iulia & NODUS & 2008-2010 & $\begin{array}{l}\text { Generalitat De } \\
\text { Catalunya (Sp.) }\end{array}$ & Urban Renewal & 254710,00 \\
\hline & Alba Iulia & $\begin{array}{l}\text { Gastronomic } \\
\text { Cities }\end{array}$ & 2013-2015 & Burgos (Sp.) & $\begin{array}{l}\text { Culture\& } \\
\text { Heritage, } \\
\text { SME's, Food }\end{array}$ & $\begin{array}{l}399969,50 \\
€\end{array}$ \\
\hline & Alba Iulia & TUTUR & 2013-2015 & Rome (It.) & \begin{tabular}{|l|} 
Abandoned \\
Spaces, Urban \\
Renewal \\
\end{tabular} & $\begin{array}{l}250000,00 \\
€\end{array}$ \\
\hline \multirow[b]{3}{*}{2} & $\begin{array}{l}\text { Baia } \\
\text { Mare }\end{array}$ & $\begin{array}{l}\text { Building } \\
\text { Healthy } \\
\text { Communities }\end{array}$ & $2008-2011$ & Turin-Italy & $\begin{array}{l}\text { Ageing, Health, } \\
\text { Participation }\end{array}$ & 635000,00 \\
\hline & $\begin{array}{l}\text { Baia } \\
\text { Mare }\end{array}$ & LUMASEC & 2008-2010 & $\begin{array}{l}\text { Universitat } \\
\text { Karlsruhe (Ge.) }\end{array}$ & $\begin{array}{l}\text { Strategic } \\
\text { Planning, } \\
\text { Urban Sprawl, } \\
\text { Urban-Rural }\end{array}$ & 250000,00 \\
\hline & $\begin{array}{l}\text { Baia } \\
\text { Mare }\end{array}$ & USEAact & 2013-2015 & Naples (It.) & \begin{tabular}{|l|} 
Strategic \\
Planning, \\
Business
\end{tabular} & 700000,00 \\
\hline \multirow[b]{2}{*}{3} & Braşov & LINKS & 2008-2011 & Bayonne (Fr)) & $\begin{array}{l}\text { Cultural } \\
\text { heritage, Urban } \\
\text { Renewal } \\
\end{array}$ & $644,400.00$ \\
\hline & Brașov & $\begin{array}{l}\text { JESSICA } 4 \\
\text { Cities }\end{array}$ & 2008-2010 & $\begin{array}{l}\text { Managing } \\
\text { Authority Erdf } \\
\text { Tuscany } \\
\text { Region (It.) }\end{array}$ & $\begin{array}{l}\text { Financial } \\
\text { Engineering }\end{array}$ & 259700,00 \\
\hline 4 & Bucharest & Open Cities & 2008-2011 & Belfast (UK) & $\begin{array}{l}\text { Education, } \\
\text { Migrants, } \\
\text { Minorities, } \\
\text { Participation }\end{array}$ & 576500,00 \\
\hline 4 & $\begin{array}{l}\text { Cluj } \\
\text { Napoca }\end{array}$ & UNIC & 2008-2012 & Limoges (FR) & \begin{tabular}{|l|} 
Traditional \\
Industries and \\
innovation \\
\end{tabular} & 634160,00 \\
\hline 4 & Galati & $\begin{array}{l}\text { FIN-URB- } \\
\text { ACT }\end{array}$ & 2010-2011 & $\begin{array}{l}\text { German } \\
\text { Association } \\
\text { For Housing, } \\
\text { Urban And } \\
\text { Spatial } \\
\text { Development } \\
\text { (Ge.) } \\
\end{array}$ & $\begin{array}{l}\text { Employment, } \\
\text { SMEs }\end{array}$ & 662800,00 \\
\hline 3 & Iași & Suite & 2009-2011 & $\begin{array}{l}\text { Santiago de } \\
\text { Compostela } \\
\text { (Sp.) }\end{array}$ & \begin{tabular}{|l|} 
Urban \\
Renewal, \\
Housing, \\
Energy \\
efficiency \\
\end{tabular} & 633237,00 \\
\hline
\end{tabular}




\begin{tabular}{|c|c|c|c|c|c|c|}
\hline & Iași & RE-block & 2013-2015 & Budapest (Hu.) & $\begin{array}{l}\text { Disadvantaged } \\
\text { Neighborhoods, } \\
\text { Housing, Urban } \\
\text { renewal, } \\
\text { Participation }\end{array}$ & 699970,00 \\
\hline & Suceava & EVUE & 2009-2012 & $\begin{array}{l}\text { Westminster } \\
\text { (UK) }\end{array}$ & $\begin{array}{l}\text { Urban mobility, } \\
\text { Electric } \\
\text { vehicules, Low } \\
\text { carbon }\end{array}$ & 425000,00 \\
\hline & Suceava & EVUE II & 2013-2015 & $\begin{array}{l}\text { Westminster } \\
\text { (UK) }\end{array}$ & $\begin{array}{l}\text { Urban mobility, } \\
\text { Electric } \\
\text { vehicules, Low } \\
\text { carbon }\end{array}$ & $624,971.21$ \\
\hline 2 & Suceava & $\begin{array}{l}\text { URBACT } \\
\text { Markets }\end{array}$ & 2013-2015 & Barcelona (Sp.) & $\begin{array}{l}\text { Local } \\
\text { Development, } \\
\text { Regeneration }\end{array}$ & 725715,56 \\
\hline 4 & $\begin{array}{l}\text { Târgu } \\
\text { Mureș }\end{array}$ & $\begin{array}{l}\text { My } \\
\text { Generation }\end{array}$ & 2008-2011 & $\begin{array}{l}\text { Rotterdam } \\
(\mathrm{Ne} .)\end{array}$ & $\begin{array}{l}\text { Youth, } \\
\text { Participation, } \\
\text { Education } \\
\end{array}$ & 637500,00 \\
\hline 4 & Timisoara & MILE & $2008-2010$ & Venice (It.) & $\begin{array}{l}\text { Migrants, } \\
\text { Inclusion, } \\
\text { Intercultural } \\
\text { Dialogue }\end{array}$ & 527503,06 \\
\hline
\end{tabular}

INTERREG IVC provides funding for interregional cooperation across Europe. It is implemented under the Cohesion policy's territorial co-operation objective and financed through the European Regional Development Fund (ERDF) from 2007 to 2013.

I have selected from INTEREG Database available on the programme's website only the projects were the competing Romanian Municipalities are involved. I did not take into consideration projects won by County Councils, Regional Development Agencies, Universities, Research Institutes or NGOs, even though I will make briefly references to them here. The reason why, in Table 3, Cluj Napoca, for example, does not appear and it is ranked the $14^{\text {th }}$, is because within the 2007-2013 period, its Municipality was not a part of an INTEREG IV C project, even though other regional actors were involved in the Programme (3 projects with the participation of the North-West Regional Development Agency, 1 project involving the National Administration "Romanian Waters," Somes Tisa River Basin Water Administrations, 1 project involving the University of Cluj Napoca and 1 project of Cluj County Council.). Also, the Municipality of Brăila is not present in the following table, even though 4 projects involved the South-East Regional Development Agency. In a similar manner, even though Municipalities of Arad or Sfântu Gheorghe were not part of INTEREG IV C projects, other regional entities participated (1 project involving Arad County Agency of Employment and the other involving the Environmental Protection Agency Covasna).

Brașov, Iași and Bucharest were the most dynamic cities in accessing these available funds. In addition, we must note that Maramureș County Council (the Municipality of Baia Mare is located in Maramureș County) also had 5 projects, independent of the City Hall, which is quite a good dynamic, comparable with the one of bigger cities/counties such as Timisoara/Timis (4 projects involving Timis Council, 1 project onvolving ADETIM - Economic and Social Development Agency of Timiş County and 4 projects involving the Regional Development Agency West Region) or even Bucharest (2 projects of the Bucharest-Ilfov Regional Development Agency, 4 of the Ilfov County, 1 project of the Executive Agency for Higher Education, Research, Development and Innovation Funding UEFISCDI, etc. ).

As a particularity regarding the statistics related to Bucharest, I should mention that one reported project was involving the Romanian Municipalities Association, based in Bucharest. (ECREIN+ European Clusters and Regions for Eco-Innovation Network Plus, project coordinated by Regional Council of Rhone-Alpes, from Lyon, France). 
Similar to the case of URBACT, no Romanian city is a Leading partner of any INTEREG IV C project. Also, among the projects' topics, we can identify the European themes such as sustainable transport, urban mobility, Information and Communication Technology (ICT), Entrepreneurship and SMEs.

Table 3. INTEREG IV C projects 2007-2013 with the participation of Romanian ECoC candidate cities (author's compilation following online data of the INTERREG IV C program)

\begin{tabular}{|c|c|c|c|c|c|c|}
\hline $\begin{array}{l}\text { Ranking } \\
\text { (No. } \\
\text { projects) }\end{array}$ & Municipality & $\begin{array}{l}\text { INTEREG IV C } \\
\text { Project Name }\end{array}$ & $\begin{array}{c}\text { Period of } \\
\text { Implementation }\end{array}$ & Lead partner & Topic & Budget \\
\hline 3 & Baia Mare & CeRamICa & 2008-2011 & $\begin{array}{l}\text { Municipality of } \\
\text { Hódmezővásárhely } \\
(\mathrm{Hu})\end{array}$ & $\begin{array}{l}\text { Cultural } \\
\text { Heritage } \\
\end{array}$ & $2,077,074.18$ \\
\hline & Brasov & Digital Cities & $2008-2011$ & $\begin{array}{l}\text { Trikala } \\
\text { Municipality (Gr.) }\end{array}$ & Innovation, ICT & $1,616,500.00$ \\
\hline & $\begin{array}{l}\text { Brasov } \\
\text { Metropolitan } \\
\text { Agency }\end{array}$ & $\begin{array}{l}\text { EPTA - European } \\
\text { model for Public } \\
\text { Transport } \\
\text { Authority }\end{array}$ & $2012-2014$ & $\begin{array}{l}\text { SRM - Networks } \\
\text { and Mobility, } \\
\text { Bologna (It.) }\end{array}$ & $\begin{array}{l}\text { Energy \& } \\
\text { sustainable } \\
\text { transport }\end{array}$ & $1,342,947.42$ \\
\hline & $\begin{array}{l}\text { Brasov } \\
\text { Metropolitan } \\
\text { Agency }\end{array}$ & $\begin{array}{l}\text { MMOVE- } \\
\text { Mobility } \\
\text { Management oVer } \\
\text { Europe: Changing } \\
\text { Mobility Patterns }\end{array}$ & 2008-2012 & $\begin{array}{l}\text { Municipality of } \\
\text { Reggio Emilia (It.) }\end{array}$ & $\begin{array}{l}\text { Energy \& } \\
\text { sustainable } \\
\text { transport }\end{array}$ & $1,851,265.02$ \\
\hline 1 & $\begin{array}{l}\text { Brasov } \\
\text { Metropolitan } \\
\text { Agency } \\
\end{array}$ & $\begin{array}{l}\text { TOK-TOC } \\
\text { Transfer Of } \\
\text { Knowledge - } \\
\text { Transfer Of } \\
\text { Human Capital } \\
\end{array}$ & 2012-2014 & $\begin{array}{l}\text { ATHENS } \\
\text { CHAMBER OF } \\
\text { SMALL \& } \\
\text { MEDIUM SIZED } \\
\text { INDUSTRIES } \\
\text { (Gr.) } \\
\end{array}$ & $\begin{array}{l}\text { Entrepreneurship } \\
\text { and SMEs } \\
\end{array}$ & $1,581,335.83$ \\
\hline \multirow[b]{2}{*}{2} & Bucharest & $\begin{array}{l}\text { CAPRICE - } \\
\text { Capital regions } \\
\text { integrating } \\
\text { collective } \\
\text { transport for } \\
\text { increased energy } \\
\text { efficiency }\end{array}$ & 2008-2011 & $\begin{array}{l}\text { Public Transport } \\
\text { Authority of } \\
\text { Berlin- } \\
\text { Brandenburg (Ge.) }\end{array}$ & $\begin{array}{l}\text { Energy and } \\
\text { sustainable } \\
\text { transport }\end{array}$ & $1,110,367.95$ \\
\hline & Bucharest & $\begin{array}{l}\text { I-SPEED } \\
\text { Information } \\
\text { Society Policies } \\
\text { for Sustainable } \\
\text { European } \\
\text { Economic } \\
\text { Development } \\
\end{array}$ & $2010-2012$ & City of Venice (It.) & $\begin{array}{l}\text { Information } \\
\text { Society }\end{array}$ & $1,402,130.84$ \\
\hline
\end{tabular}




\begin{tabular}{|c|c|c|c|c|c|c|}
\hline & Iași & $\begin{array}{l}\text { E-COOP } \\
\text { DIGITAL } \\
\text { COOPERATIVES }\end{array}$ & 2012-2014 & $\begin{array}{l}\text { Gironde County } \\
\text { Council, Bordeaux } \\
\text { (Fr.) }\end{array}$ & $\begin{array}{l}\text { Information } \\
\text { Society }\end{array}$ & $2,240,104 \cdot 12$ \\
\hline & Iași & $\begin{array}{l}\text { ERMIS - } \\
\text { Effective } \\
\text { Reproducible } \\
\text { Model of } \\
\text { Innovation } \\
\text { Systems } \\
\end{array}$ & 2010-2012 & $\begin{array}{l}\text { Chamber of } \\
\text { Commerce French } \\
\text { Riviera, Nice (Fr.) }\end{array}$ & $\begin{array}{l}\text { Innovation, } \\
\text { research and } \\
\text { technology } \\
\text { development }\end{array}$ & $2,075,867.50$ \\
\hline & Iași & $\begin{array}{l}\text { ORGANZA - } \\
\text { Network of } \\
\text { Medium Sized } \\
\text { Creative Cities }\end{array}$ & 2010-2012 & $\begin{array}{l}\text { Municipality of } \\
\text { Arnhem (Ne.) }\end{array}$ & $\begin{array}{l}\text { Entrepreneurship } \\
\text { and SMEs }\end{array}$ & $1,959,881.25$ \\
\hline 1 & Iași & $\begin{array}{l}\text { PLUS - Public } \\
\text { Lighting } \\
\text { Strategies for } \\
\text { Sustainable Urban } \\
\text { Spaces }\end{array}$ & 2010-2012 & $\begin{array}{l}\text { Eindhoven } \\
\text { Municipality (Ne.) }\end{array}$ & $\begin{array}{l}\text { Energy and } \\
\text { sustainable } \\
\text { transport }\end{array}$ & $1,689,508.00$ \\
\hline 3 & Timisoara & PIMMS Transfer & $2008-2011$ & London (UK) & Urban Mobility & $3,017,039.00$ \\
\hline
\end{tabular}

\section{Horizontal Europeanization through twinning agreements}

Regarding the location of cities with whom Romanian municipalities decided to twin, we can observe (Table 4) the existence of some exotic locations, such as Asia, Africa, and ex-soviet space, mostly concluded during the communist period and others concluded immediately after the democratization of the Romanian political regime (twinnings with US cities.)

Table 4. Twinning agreements of Romanian ECoC candidate cities (author's compilation of public data existent on City Halls websites)

\begin{tabular}{|c|l|l|l|l|}
\hline No. & \multicolumn{1}{|c|}{ City } & \multicolumn{1}{|c|}{ Twin cities } & \multicolumn{1}{|c|}{ Agreements/Rank } \\
\hline 1 & Alba Iulia & $\begin{array}{l}\text { Aeghio (Gr.), Alcala de Henares (Sp.), Alessandria (It.) Arnsberg } \\
\text { (Ge.), Biograd na Moru (Cro.), Chişinău (Md.), Duzce (Tur.), } \\
\text { Lanzhou (Chi.), Nazareth Illit (Isr.), San Benedetto del Tronto } \\
\text { (It.), Sliven (Bg.), Székesfehérvár (Hu.), Varese (It.), Viadana } \\
\text { (It.) }\end{array}$ & 14 & 4 \\
\hline 2 & Arad & $\begin{array}{l}\text { Zrenjanin (Ser.), Atlit (Isr.), Fushun (Chi.), Gyula (Hu.), } \\
\text { Hodmezovasarhely (Hu.), Pecs (Hu.), Givataym (Isr.), Heist-op- } \\
\text { den-Berg (Bel.), Praga - Sector 5 (Ceh.) }\end{array}$ & 9 & 7 \\
\hline 3 & Baia Mare & $\begin{array}{l}\text { Kitwe (Zam.), Szolnok (Hu.), Ivano Frankivsk (Ucr.), Wels } \\
\text { (Au.), Hollywood (US), Bielsko Biala (Po.), Hódmezovásárhely } \\
\text { (Hu.), Nyíregyháza (Hu.), Serino (It.). }\end{array}$ & 9 & 7 \\
\hline 4 & Brăila & $\begin{array}{l}\text { Calais (Fr.), Plevna (Bg.), Katerini (Gr.), Nilufer (Tur.), Bitola } \\
\text { (Mac.), Kavadarci (Mac.), Denizli (Tur.), Argostoli (Gr.). }\end{array}$ & 8 & 8 \\
\hline 5 & Bucharest & $\begin{array}{l}\text { Athens (GR.), Atlanta (US), Pretoria (Southy Africa), Ankara } \\
\text { (Tur.), Amman (Jordan), Chisinau (Md), Beijing (Chi), Nicosia } \\
\text { (Ci) }\end{array}$ & 8 & 8 \\
\hline 6 & Cluj Napoca & $\begin{array}{l}\text { Dijon (Fr.), Nantes (Fr.), Zagreb (Cr.), Koln (Ge.), Pecs (Hu.), } \\
\text { Columbia (US), Bețer Sheva (Isr.), Zengzhou (Chi.), Suwon }\end{array}$ & 20 \\
\hline
\end{tabular}




\begin{tabular}{|c|l|l|l|l|}
\hline & & $\begin{array}{l}\text { (Cor.), Makati (Fil.), Chacao-Caracas (Ven.), Sao Paolo (Bra.), } \\
\text { Korce (Alb.), Parma (It.), Rockford (US), East Lansig (US), } \\
\text { Rotherham (UK), Namur (Be.), Viterbo (It.) Ningbo (Chi.) }\end{array}$ & & \\
\hline 7 & Craiova & $\begin{array}{l}\text { Kuopio (Finl.), Shyan (Chi.), Nanterre (Fr.), Vratza (Bg.), Skopje } \\
\text { (Mac.). }\end{array}$ & 5 & 9 \\
\hline 8 & Iași & $\begin{array}{l}\text { Poitiers (Fr.), Xi'an (Chi.), Monterrey (Mex.), Vinita (Ucr.), } \\
\text { Padova (It.), Isfahan (Iran), Sant'oreste (It.), Athens (US)., } \\
\text { Persiteri (Gr.), Villeneuve D'ascq (Fr.), Jerihon (Pal.), Velico } \\
\text { Tarnovo (Bg.), Ilioupolis (Gr.), Chisinau (Md.), Cernauti (Ucr.). }\end{array}$ & 15 & 3 \\
\hline 9 & $\begin{array}{l}\text { Sf. } \\
\text { Gheorghe }\end{array}$ & $\begin{array}{l}\text { Alsónána (Hu.), Cegled (Hu.), Ferencvaros (Hu.), Kecskemet } \\
\text { (Hu.), Kisbucsa (Hu.), Kiskunhalas (Hu.), Mosonmagyaróvár } \\
\text { (Hu.), Sarpilis (Hu.), Veszprem (Hu.), Královský Chlmec (Sk.), } \\
\text { Magyarkanizsa (Ser.), Santa Cruz (Pt.), Givatayim (Isr), Saint } \\
\text { George Sur Cher (Fr.), Sfântu-Gheorghe (Ro.), Novosibirsk } \\
\text { (Rus.). }\end{array}$ & 16 & 2 \\
\hline 10 & Suceava & $\begin{array}{l}\text { Cernauti (Ucr.), Sosnowiec (Pol.) } \\
\text { Tournemouth (UK.), Ilmenau (Ge.), Szeged (Hu.), Kekskemet } \\
\text { (Hu.), Budapesta (Hu.), Zalaegerszeg (Hu.), Baja (Hu.), Chisinau } \\
\text { (Md.), East Renfrewshire (UK.), Guzelcamli (Tur.) }\end{array}$ & 10 & 6 \\
\hline 11 & Tg. Mureș & $\begin{array}{l}\text { Graz (Aus.), Mulhouse (Fr.), Faenza (It.), Karlsruhe (Ge.), Rueil- } \\
\text { Malmaison (Fr.), Szeged (Ung.), Gera (Ge.), Treviso (It.), Novi } \\
\text { Sad (Ser.), Palermo (It.), Nottingham (UK), Cernăuți (Ucr.), } \\
\text { Trujillo (Peru) }\end{array}$ & 13 & 5 \\
\hline
\end{tabular}

Today, $70 \%$ of these agreements are concluded with European cities (Fig.1.). We can observe a specialization of twinning between similar cities, which share common problems or profiles and can exchange best practices. In support of this argument, it is understandable the preference of Sfantu Gheorghe and Targu Mures for twinnings with Hungarian cities, giving the existence of a strong Hungarian minority within these cities. We can also observe the prevalence of the geographical proximity of present twin cities, agreements being concluded between neighbour transborder cities. This is the case of Baia Mare (Ivano Frankivsk, Nyíregyháza), Iasi (Chisinau, Cernauti), Timisoara (Szeged, Novi Sad), Suceava (Cernauti), Arad (Gyula) or Craiova (Vratza).

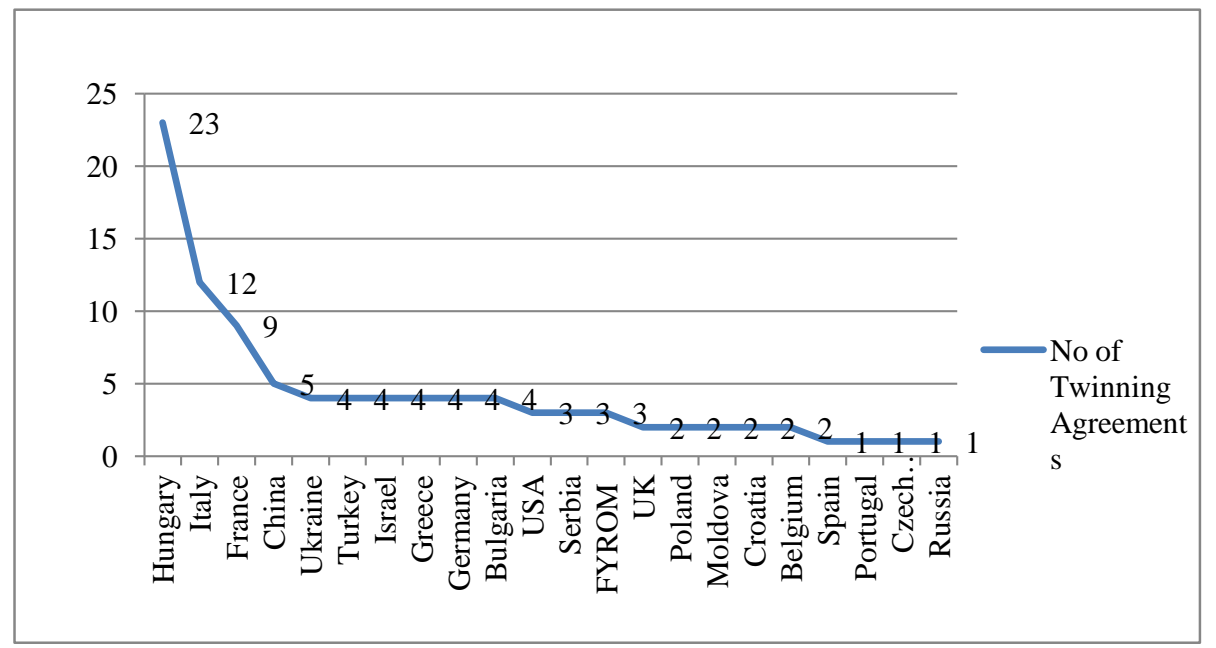

Fig. 1. Partner countries of the Twinnings Agreements of Romanian ECoC candidate cities (Author's compilation of existing public data) 
It is also important to note that Baia Mare is the only city among the 14 analysed ones, to have a twinning agreement with a city who is the Leading partner of an INTEREG IV C project (Hódmezovásárhely). This means that in the case of other 13 cities, city twinning agreements map does not intersect the regional financing networks. This can be considered a lost opportunity to use the soft urban diplomacy of twinning, for regional development purposes.

\section{Conclusions}

Considering Europeanization as an opportunity to create new political spaces for cities, this study analyses the Europeanization of Romanian cities competing for the 2021 ECoC title. A variety of horizontal, bottom-up and top-down Europeanization behaviours have been found, such as joining Urban Networks, signing Twinning Agreements or accessing Territorial Cooperation Funds. Relatively new in the EU context, Romanian post-socialist cities do not seem to understand the importance of networking. Some of them don't even promote on their websites their membership to urban networks or existent twin agreements. And even when they are a part of an urban network (mainly the large and wealthier cities) they do not assume a leading role and seem to resume at learning from others, which is still a plus. While Romanian cities do not value the traditional twinning method of internationalisation, they prefer project-based, often time-limited cooperation, within URBACT II or INTEREG IV C. There too, Romanian cities did not assume leading Roles. Some cities have been more active than other, and summing up cities' rankings for each type of activity, leads to the results from Table 5 .

Table 5. Indicators of Europeanization of Romanian ECoC candidate cities. Rankings

\begin{tabular}{|r|l|l|l|l|l|l|l|}
\hline No. & City & $\begin{array}{c}\text { Urban } \\
\text { Networks } \\
\text { Ranking }\end{array}$ & $\begin{array}{c}\text { Twinning } \\
\text { Agreements } \\
\text { Ranking }\end{array}$ & $\begin{array}{c}\text { URBACT } \\
\text { Projects } \\
\text { Ranking }\end{array}$ & $\begin{array}{c}\text { INTEREG } \\
\text { IV C } \\
\text { Projects } \\
\text { Ranking }\end{array}$ & $\begin{array}{c}\text { Total } \\
\text { Points }\end{array}$ & $\begin{array}{l}\text { General } \\
\text { Ranking }\end{array}$ \\
\hline 1 & Alba Iulia & 2 & 4 & 1 & 14 & 21 & 4 \\
\hline 2 & Arad & 3 & 7 & 14 & 14 & 38 & 9 \\
\hline 3 & $\begin{array}{l}\text { Baia } \\
\text { Mare }\end{array}$ & 6 & 7 & 2 & 3 & 18 & 3 \\
\hline 4 & Brașov & 4 & 14 & 3 & 1 & 22 & 5 \\
\hline 5 & Brăila & 14 & 8 & 14 & 14 & 50 & 12 \\
\hline 6 & București & 4 & 8 & 4 & 2 & 18 & 3 \\
\hline 7 & $\begin{array}{l}\text { Cluj } \\
\text { Napoca }\end{array}$ & 5 & 1 & 4 & 14 & 24 & 6 \\
\hline 8 & Craiova & 14 & 9 & 14 & 14 & 51 & 13 \\
\hline 9 & Galați & 14 & 14 & 4 & 14 & 46 & 11 \\
\hline 10 & Iași & 3 & 3 & 3 & 1 & 10 & 1 \\
\hline 11 & $\begin{array}{l}\text { Sf. } \\
\text { Gheorghe }\end{array}$ & 6 & 2 & 14 & 14 & 36 & 8 \\
\hline 12 & Suceava & 14 & 10 & 2 & 14 & 40 & 10 \\
\hline 13 & $\begin{array}{l}\text { Tg. } \\
\text { Mureș }\end{array}$ & 6 & 6 & 4 & 14 & 30 & 7 \\
\hline 14 & Timișoara & 1 & 5 & 4 & 3 & 13 & 2 \\
\hline
\end{tabular}


By the time I finished this paper the preliminary results of Romanian ECoC preselection were available, in December 2015. ${ }^{34}$ The shortlist of finalist candidates is composed by Baia Mare, Bucharest, Cluj Napoca and Timisoara. All the finalist cities have good rankings of Europeanization, according to my study, which is an interesting confirmation of my results. And even though the presence on the shortlist of the small mining city of Baia Mare, was considered to be a surprise, this study confirms the European dynamic of the city and its well worth place. The big defeated in this preliminary competition are Iasi, Alba Iulia and Brasov: even if, according to my study, they had Europeanized profiles prior to the competition, probably these cities did not prepare a good ECoC Dossier, in terms of Cultural Strategy ${ }^{35}$ and Bid Book. These subjects can be approached in future studies.

\section{References}

"Baia Mare, București, Cluj-Napoca şi Timişoara, pe lista scurtă a oraşelor preselectate" [Baia Mare, București, Cluj-Napoca and Timişoara on the official shortlist of selected cities], 2021 ECoC Romania Official Website http://www.capitalaculturala2021.ro/noutati_doc_24_baia-marebucuresti-cluj-napoca-si-timisoara-pe-lista-scurta-a-oraselor-preselectate_pg_0.htm, (accessed december 2015)

Cogliandro, G. "European cities of culture for the Year 2000: A wealth of urban cultures for celebrating the turn of the century." Association of the European Cities of Culture of the year 2000 (2001) : 1-143.

Heinelt, H., Niederhafner, S. "Cities and organized interest intermediation in the EU multi-level system." European Urban and Regional Studies 15(2) (2008): 173-187.

Jayne, M., Hubbard, P. and Bell, D. "Twin Cities: Territorial and Relational Geographies of 'Wordly' Manchester." Urban Studies 50 (2) (2013): 239-254.

John, P. “The Europeanization of Sub-national Governance.” Urban Studies 37, 5-6 (2000): 877-894.

Kern, K., Bulkeley, H. "Cities, Europeanization and Multi-level Governnace: Governing Climate Change through Transnational Municipal Networks." Journal of Common Market Studies 47 (2) (2009): 309-332.

Lackowska, M. "Polish Cities Face the EU - Europeanization of Post-Socialist Cities as a Type of Outward Political Rescaling." Croation and Comparative Public Administration (2014): 31-58.

Leitner, H., Sheppard, E. " 'The City is Dead, Long Live the Net': Harnessing European Interurban Networks for a Neoliberal Agenda." Antipode (2002): 495-518.

Marks, G."Structural policy and Multilevel Governance in the EC." in The State of the European Community, ed. Alan Cafruny and Glenda Rosenthal, 391-411, Boulder: Lynne Rienner, 1993.

Marks, G., Hooghe, L. "Unraveling the Central State, But How? Types of Multi-Level Governance." Political Science Series 87 ( 2003): 2-19.

Steiner, L., Frey, B. and Hotz, S. "European Capitals of Culture and life satisfaction." Urban Studies 52 (2) (2015) : 374-394.

Tolle, A. "Transnationalism of development strategies in East Central European cities: A survey of the shortlisted Polish European Capital of Culture candidate cities." European Urban and Regional Studies 0 (2013) : 1-15.

http://eur.sagepub.com/content/early/2013/12/29/0969776413512845.full.pdf+html (accessed Dec. 2015)

34 "Baia Mare, Bucureşti, Cluj-Napoca şi Timişoara, pe lista scurtă a oraşelor preselectate" [Baia Mare, Bucureşti, Cluj-Napoca and Timişoara on the official shortlist of selected cities], http://www.capitalaculturala2021.ro/noutati_doc_24_baia-mare-bucuresti-cluj-napoca-si-timisoara-pe-listascurta-a-oraselor-preselectate_pg_0.htm, (accessed december 2015).

35 See also C. Turșie, "Urban challenges: Romanian candidate cities for the 2021 European capital of culture title: smart, sustainable and inclusive cities?", Proceedings of the 2nd CommScie International Conference "Challenges for Sciences and Society in Digital Era” (Iasi: Pim, 2015): 132-139. 
Turșie, C. "Urban challenges: Romanian candidate cities for the 2021 European capital of culture title: smart, sustainable and inclusive cities?" Proceedings of the 2nd CommScie International Conference "Challenges for Sciences and Society in Digital Era (2015): 132-139.

Steiner, L., Frey, B. and Hotz, S. "European Capitals of Culture and life satisfaction." Urban Studies 52 (2) (2015) : 374-394.

City Hall Websites of: Alba Iulia, Arad, Baia Mare, Brașov, Brăila, București, Cluj Napoca, Craiova, Galați, Iași, Sfântu Gheorghe, Suceava, Târgu Mureș, Timișoara (accessed November-December 2015)

URBACT II Website: http://urbact.eu/\# (accessed December 2015)

INTEREG IV C Website http://www.interreg4c.eu/ (accessed December 2015)

E-mail correspondence:

Ardelean, V., Communication Office, Baia Mare City Hall, Official email correspondence (November 2015).

Botezan, E., Head of International Affairs and Foreign Investment Department Cluj-Napoca City Hall, Official email correspondence (November 2015).

Donawell, D. "Timisoara City Hall- Associations and International Urban Network", Timisoara City Hall International Relations Office, Official email correspondence (December 2015).

Knop, I., Counsellor Town Hall of Sfântu Gheorghe, Official email correspondence (November 2015).

Moldovan, N., City Manager Alba Iulia Municipality, Official email correspondence (November 2015).

Zamfir, G., Executive Director, Bucharest City Hall, General Secretary, Juridical and Techincal Assistance Department, Address No. 4705-542L/3/19.11.2015. 